\title{
The Functional Representation of the Individual's Interests Before the EC Courts: The Evolution of the Remedies System and the Pluralistic Deficit in the EC
}

Luigi Mmalferrari

Court of First Instance of the European Communities

Follow this and additional works at: https://www.repository.law.indiana.edu/ijgls

Part of the Courts Commons, European Law Commons, and the International Law Commons

\section{Recommended Citation}

Mmalferrari, Luigi (2005) "The Functional Representation of the Individual's Interests Before the EC Courts: The Evolution of the Remedies System and the Pluralistic Deficit in the EC," Indiana Journal of Global Legal Studies: Vol. 12 : Iss. 2 , Article 15.

Available at: https://www.repository.law.indiana.edu/ijgls/vol12/iss2/15

This Symposium is brought to you for free and open access by the Law School Journals at Digital Repository @ Maurer Law. It has been accepted for inclusion in Indiana Journal of Global Legal Studies by an authorized editor of Digital Repository @ Maurer Law. For more information, please contact rvaughan@indiana.edu. 


\title{
The Functional Representation of the Individual's Interests Before the EC Courts: The Evolution of the Remedies System and the Pluralistic Deficit in the EC
}

\author{
Luigi Malferrari*
}

\section{INTRODUCTION}

Given the democratic deficit affecting Community governance, the representation of the individual's interests through tools that are different from the traditional political ones is particularly necessary and important in the European Community (EC). ${ }^{1}$ Although such alternative tools cannot substitute for the political channels of interest representation, they can integrate them and they are essential to enhance the effectiveness of the representation of the individual's rights and the respect of the rule of law. Given the difficulties citizens and enterprises experience in making their voices heard by the EC political institutions (Council, Commission, and Parliament) and national governments, sometimes the only feasible channel for effectively pursuing their interests is the judicial one. At the same time, the increasing "juridification" of society has turned judicial processes into sites of policymaking within the Community as well. As a result, the functional representation of individual interests before the courts plays a crucial role in the EC.

To be effective, the functional representation of the individual's interests before courts presupposes three elements. First, individuals must have sufficient access to courts. Second, the individual's interests must be taken into account in

* Référendaire, Court of First Instance of the European Communities; chargé de cours, Université Robert Schuman de Strasbourg (malferrari@gmx.net). LL.B., University of Bologna, Italy; LL.M., Harvard Law School; Doctorate, University of Heidelberg, Germany. I would like to thank Miriam Aziz, Julio Baquero Cruz, Marco Dani, Nicoletta Falcone, Kirsten Roberts, Louise Robinson, Peter Teachout, and Lorna Young for precious input on the substance and language of this paper. However, the content of this paper reflects only my personal views, and any error of law or fact is solely my responsibility. A previous version of this paper was delivered at the symposium Back to Government? The Pluralistic Deficit in Decisionmaking Processes and Before the Courts held on June 11 and 12, 2004 at the University of Trento, Italy.

1. See Henry G. Schermers \& Denis F. Waelbroeck, Judicial Protection in the European UNION $\S 629$, at 310 (6th ed. 2001). 
judgments. Third, those judgments must be enforced. This article will focus on the first element, whereas it will only touch on the second and third elements.

The aim of this article is thus twofold. First, it illustrates the development of the different avenues that allow the functional representation of the individual's interests before the EC courts. Such avenues are described and critically assessed in regard not only to their aptness to ensure effective interest representation, but also to their impact on European, as well as national, governance. Second, building on this assessment, the paper will discuss possible reforms of the EC judicial remedies with a view to improving or at least maintaining their effectiveness as tools for the functional representation of the individual's interests.

\section{The Tools for the Individual's Interest Representation Before THe EC Courts}

Before tackling the question of the reform of the EC remedies system, it is necessary to analyze and assess its development from the perspective of the individual's interest representation. The functional representation of the individual's interests before the EC courts is achieved basically through two avenues: 1) access to the EC judiciary in its function as supreme and/or constitutional court and 2) access to the EC judiciary in its function as administrative court.

\section{A. Interest Representation through Supreme or Constitutional Adjudication}

The main and foremost tool for the judicial interest representation at the EC level is doubtlessly the adjudication by the European Court of Justice (ECJ), acting in its role as supreme and constitutional court. This type of adjudication can be achieved in two ways. The first and more relevant one is the preliminary ruling procedure under Article 234 of the EC Treaty (ECT). ${ }^{2}$ The second is the infringement action that can be brought by the Commission against a Member State under Article 226 of the ECT.

\section{Preliminary Ruling Procedure}

The basic traits of the preliminary ruling procedure under Article 234 of the ECT are generally well-known. They will be very briefly recalled here for the

2. Consolidated Version of the Treaty Establishing the European Community, Dec. 24, 2002, O.J. (C 325) 33 (2002) [hereinafter EC TREATY]. 
sake of clarity. Where a dispute before a national judge poses a question regarding the interpretation of EC law, he (usually spurred by the parties) may or, if it is a court of last instance, must refer this question to the ECJ. To this effect, the national judge suspends proceedings and sends his referral to the EC) in Luxembourg. After the ECJ has issued its ruling in reply to the question referred, the national judge resumes proceedings and decides the case on the basis of the ECJ's answer.

The preliminary ruling procedure has the nature of constitutional adjudication because it enables the ECJ to scrutinize the compatibility of EC legislation with primary EC law such as the Treaties and, albeit indirectly, the compatibility of national legislation with EC law. It is also tantamount to a supreme court adjudication because, although not being a cassation review, it allows the ECJ to give the ultimate interpretation of EC law. It should be noted that by interpreting EC law, the ECJ also influences the manner in which national law is interpreted. For example, the interpretation of a directive dictates the way the national implementing law is interpreted. Similarly, by saying under which circumstances a national provision is compatible with EC law, a preliminary ruling by the ECJ affects the interpretation of that provision. ${ }^{3}$

All this may appear surprising given the international law origins of the EC Treaties and the rather limited wording of Article 234 of the ECT. It is indeed through an evolutionary and audacious interpretation of the EC Treaties as well as a strategically smart use of the Article 234 procedure that the ECJ has built such a complex, quasi-federal judicial architecture.

The ECJ first read into the Treaties the direct effect of EC law and its supremacy over national law of any nature, even constitutional. ${ }^{4}$ It then found that unimplemented directives may have, at least against the defaulting state, direct effect if their content is sufficiently precise. ${ }^{5}$ It further ruled that a national law transposing a directive must be interpreted, so far as possible, "in light of the

3. But cf. id. $\S 1312$, at 648 (offering the critique that the ECJ "should not be entitled to indicate in a preliminary ruling that a particular national legislation is in conformity with [European] Community law").

4. See Case 26/62, N.V. Algemene Transport-en Expeditie Onderneming van Gend \& Loos v. Nederlandse administratie der belastingen, 1963 E.C.R. 1, Grounds of the Judgment, pt. III.B., at 13 ("Article 12 must be interpreted as producing direct effects. ..."); Case 6/64, Costa v. ENEL, 1964 E.C.R. 585, 599 ("[U]nilateral measure cannot take precedence over Community law. ...").

5. Case 148/78, Pubblico Ministero v. Ratti, 1979 E.C.R. 1629, Grounds of the Judgment, para. 23. 
wording and the purpose of the directive in order to achieve the result pursued by the latter." Further, it retained for itself the monopoly over the review of the validity of EC measures ${ }^{7}$ and construed very narrowly the doctrine of acte-clair, which some national courts had developed as an exception to the obligation to refer for national courts of last instance under Article 234(3) of the ECT. ${ }^{8}$ The ECJ also ruled that national procedural rules may not protect rights flowing from EC law less vigorously than those ensuing from national law, and in any event, that these rules must be interpreted in such a way as to ensure the effectiveness of EC law. ${ }^{9}$ Additionally, it deemed that human rights, although not explicitly recognized in the EC treaties, form part of EC law and must be observed not only by EC legislation, but also by national legislation falling within the scope of application of EC law. ${ }^{10}$ Finally, it found that Member States-under certain circumstances—are liable for the damages resulting from nonimplementation of a directive and, more generally, for violations of EC law. ${ }^{11}$

This far-reaching case law did not remain dead letter precisely because the ECJ made use of the preliminary ruling procedure as a means of establishing a dialogue and, despite some "rebellions," an alliance with national courts (especially inferior and middle courts), which have thus become the ordinary courts of EC law. The minimal requirements for admissibility of preliminary references, the compelling persuasiveness of the ECJ's reasoning in most judgments, and the empowerment of national courts vis-à-vis superior courts as well as the

6. Case C-106/89, Marleasing SA v. La Comercial Internacional de Alimentación SA, 1990 E.C.R. I-4135, Grounds of the Judgment, para. 8.

7. See Case 314/85, Foto-Frost v. Hauptzollamt Lübeck-Ost, 1987 E.C.R. 4199, Grounds of the Judgment, para. 20.

8. See Case 283/81, Srl CILFIT v. Ministry of Health, 1982 E.C.R. 3415, Grounds of the Judgment, paras. $14,16$.

9. See Case 222/84, Johnston v. Chief Constable of the Royal Ulster Constabulary, 1986 E.C.R. 1651, Grounds of the Judgment, para. 18; Case C-312/93, Peterbroeck v. Belgian State, 1995 E.C.R. I-4599, Grounds of the Judgment, paras. 12-21; Case C-327/00, Santex SpA v. Unità Socio Sanitaria Locale No. 42 di Pavia, 2003 E.C.R. I-1877, Grounds of the Judgment, para. 56. The $\mathrm{ECJ}$ has ruled, for example, that where necessary, national judges must issue interim measures against national rules infringing EC law, although national procedural rules do not provide for such possibility.

10. See Case C-260/89, Elliniki Radiophonia Tiléorassi (ERT) AE v. Pliroforissis, 1991 E.C.R. I2925, Grounds of the Judgment, para. 41.

11. See Joined Cases C-6/90 \& C-9/90, Francovich v. Italian Republic, 1991 E.C.R. I-5357, Grounds for Judgment, paras. 35-36; Joined Cases C-46/93 \& C-48/93, Brasserie du Pêcheur SA v. Germany, 1996 E.C.R. I-1029, Grounds of the Judgment, paras. 17-36. 
legislator, are elements that can explain why Article 234 of the ECT has become the means for spreading and imposing the application of EC law throughout the Community.

The involvement of national judges, although it has sometimes posed certain difficulties, has been the main thrust and advantage of the preliminary ruling procedure. Because it is a national court that applies EC law, this new legal order has acquired the formal authority and enforcement tools that characterize national legal systems. ${ }^{12}$ Thus, because of the ever-increasing use of Article 234 of the ECT, Community law has left the shaky realm of international law and has become equivalent to the supreme law of the land in every Member State.

Under these circumstances, the implications for the representation of the individual's interests before the EC judiciary are numerous and far-reaching. First, to claim the protection of the rights flowing from EC law is easy or, at least, not more difficult and costly than to claim the protection of rights flowing from national law. ${ }^{13}$ Indeed, even the lowest national court can become the gateway to enforcing EC law (think of the Giudice conciliatore ${ }^{14}$ of Milan who was the referring judge in the landmark case Costa/ENEL!). Given that it is the national judge who refers the question to the ECJ, the parties are required to know nothing more than national procedural rules. Nor must they pay any extra legal fees, because the use of Article 234 of the ECT is free. On the other hand, this

12. See Karen J. Alter, Who Are the "Masters of the Treaty"?: European Governments and the European Court of Justice, 52 Int'l Org. 121, 126 (1998); Renaud Dehousse, The European Court of Justice: The Politics of Judicial Integration 30-34 (1998); J.H.H.Weiler, The European Court, National Courts and References for Preliminary Rulings-The Paradox of Success: A Revisionist View of Article 177 EEC, in Article 177 EEC: Experiences and Problems 366, 367 (Henry G. Schermers et al. eds., 1987) [hereinafter The European Court]; J.H.H. Weiler, The Least Dangerous Branch: $A$ Retrospective and Prospective of the European Court of Justice in the Arena of Political Integration, in The Constitution of Europe: "Do the New Clothes Have an Emperor?" and Other Essays on European Integration 188, 194-95 (1999) [hereinafter The Least Dangerous Branch]; J.H.H. Weiler, Journey to an Unknown Destination: A Retrospective and Prospective of the European Court of Justice in the Arena of Political Integration, 31 J. Cоммоn Мкт. Stud. 417, 422-23 (1993) [hereinafter Journey to an Unknoun Destination]. Cf. Gil Carlos Rodríguez Iglesias, Der Europäische Gerichtshof und die Gerichte der Mitgliedstaaten: Komponenten der Richterlichen Gewalt in der EuropäIsChen Union (2000).

13. Cf. Harm Schepel \& Erhard Blankenburg, Mobilizing the European Court of Justice, in THE European Court of Justice 9, 42 (Gráinne de Búrca \& J.H.H. Weiler eds., 2001). But see Case C50/00 P, Unión de Pequeños Agricultores v. Council, 2002 E.C.R. I-6677, Opinion of the Advocate General, para. 44.

14. The Giudice conciliatore is the lowest court in Italy and is in charge of small claims. 
brings with it a disadvantage that is probably inevitable: where a national judge does not refer a question, the individuals may not bring the matter before the ECJ of their own accord..$^{15}$

Second, some individual interests, which before the EC Treaties were left without effective remedies, can now be protected by national courts. This is particularly important, because before the EC Treaties came into force, transnational trade in Europe was governed by either no rules or international law. As a result, the remedies for the individual were limited: one could try to claim (maybe before a foreign court) the application of international law or induce the home government to act through diplomatic channels. Both remedies, however, were often costly and fruitless. By contrast, on the basis of EC law, the individual's interests regarding international trade can be put forward in the form of legal arguments, which, if accepted and applied by the court, can entail direct legal consequences. ${ }^{16}$

Third, the supremacy of EC law over national law of any nature, even constitutional, has marked the reduction of parliamentary supremacy in those Member States where it still existed (for example in the United Kingdom). Thus, in these Member States, EC law litigation has opened to the individual the possibility to assert his rights even against the national legislator's will.

Fourth, European integration consists partly of the elimination of national barriers to freedom of trade, movement, services, establishment, flow of capital, and competition. To the extent that such "negative integration" is sufficient and does not necessarily require any action by the national or European legislator, European integration can be adequately accomplished by means of judicial rulings declaring the incompatibility of national rules with EC law. ${ }^{7}$ At the same time, the rulings of the ECJ have also "positively" influenced not only the Community legislator, but also the national legislators, who in many instances have conformed their past and present legislation to the ECJ's constraints. ${ }^{18}$ Sometimes an EC legislator has even been spurred by ECJ rulings to enact legislation on a particular matter. An example of this is the EC legislation on the mutual recognition of national standards, following the Cassis de Dijon ruling. ${ }^{19}$

15. Cf. infra note 85 and accompanying text.

16. Cf. Alec Stone Sweet, Governing with Judges: Constitutional Politics in Europe 140 (2000) (discussing how individuals effect change in constitutional law through litigation).

17. See id. at 157.

18. See id. at $157,181$.

19. Case 120/78, Rewe-Zentra AG v. Bundesmonopolverwaltung für Branntwein ("Cassis de Dijon"), 1979 E.C.R. 649, Grounds of the Judgment, para. 15. 
Moreover, EC law has bestowed upon individuals "new" rights, for example the rights flowing from the EC competition rules. Given the direct applicability and supremacy over domestic law of Article 81(1)(2) of the ECT and Article 82 of the ECT, companies have been able to go to court and ask for the protection of their rights under these provisions in order to compete freely and on the basis of the merits of their products or services. ${ }^{20}$ These rights constituted a legal novelty in those Member States, such as Italy, where national antitrust rules did not exist when the EC Treaty came into force. ${ }^{21}$

Additionally, the individual's interests that, despite their being recognized in the national codes and constitution, have been neglected at the national level because they were not given priority over other conflicting values, can now find a potentially more favorable forum in Luxembourg. The more vigorous protection by the ECJ of some interests can be explained by considering the ECJ's different perspective, taking into account the European rather than the national interest, its mixture of legal cultures, and its concept of substantive rather than formalistic justice. The protection of the individual's rights thus achieved found an objective justification in the need to foster European integration, which in most Member States has been a generally accepted value. ${ }^{22}$

To afford such protection of the individual's EC law rights, the ECJ relied on the wording of the EC provisions, but also had recourse (sometimes controversially) to teleological and effet-utile interpretative canons. Despite the entry into force of the founding Treaties, the EC legal order remained in many regards incomplete. In some fields, the stalemate of the EC legislative process meant that the only way to achieve legal rules was through judicial interpretation. When confronted with the need for filling the lacunae of the EC legal order, the ECJ often demonstrated creativity as well as audacity in interpreting the EC Treaties. An example thereof, in accordance with the principle of legal certainty, is the "creation" of a two-month time limit for the Commission to decide whether a notified state aid can be cleared or must be subjected to closer scrutiny under the Treaty rules on state aid. ${ }^{23}$ It is worth noting that because the ECJ read such rules as being implied in the Treaties, their rank is that of primary law and,

20. EC Treaty art. 81(3) (entered into force May 1, 2004) is also directly applicable.

21. The Italian antitrust law was not enacted until 1990.

22. Renaud Dehousse, La Cour de Justice des Communautés Européennes 109 (1994).

23. Case 123/73, Gerb. Lorenz GmbH v. Germany, 1973 E.C.R. 1471, Grounds of the Judgment, para. 4. 
as such, they cannot be changed by secondary legislation. Therefore, the individual's interests in question are more vigorously protected than if the same rules had been enacted by the EC legislator through secondary legislation.

Finally, the need to protect the individual's interests has contributed to the legitimization of the ECJ and EC law in general. The fact that it has been "fleshand-blood" persons seeking justice through EC law has helped the ECJ to gain acceptance of audacious judgments, as well as cement its legitimacy and authority in its role as constitutional and supreme court in the Community. ${ }^{24}$ For example, the introduction of the principle of state liability for violation of EC law ("Francovich liability") was somewhat easier because the case at issue concerned the guarantee of employees' wages in the event of insolvency of their employer, and so raised an important and urgent social rights question. ${ }^{25}$ It thus combined such compelling elements as vulnerable individuals, fundamental rights, and state noncompliance with EC law. ${ }^{26}$

In sum, the preliminary ruling procedure, despite some shortcomings, has proved on the whole to be a successful tool for the representation of the interests of the individual. The EC litigation that has been fueled through the Article 234 procedure has played a role "to emancipate civil society, rationalize administration, ... curb raw political power," ${ }^{27}$ and ensure the rule of law. The willingness of private litigants to invoke EC law and the spirit of cooperation of national courts have been key ingredients of this success story. ${ }^{28}$ However, precisely because of this success, as well as owing to a few unfortunate legislative choices, the preliminary ruling procedure today runs the risk of losing part of its effectiveness. ${ }^{29}$

24. See Claire Kilpatrick, Turning Remedies Around: A Sectoral Analysis of the Court of Justice, in The European Court of Justice, supra note 13, at 143, 143; HJalte Rasmussen, On Law and Policy in the European Court of Justice: A Comparative Study in Judicial Policymaking 9 (1986). Cf. SweEt, supra note 16, at 140-41 (discussing how individuals effect change in constitutional law through litigation). But see Marie-Pierre F. Granger, When Governments Go to Luxembourg...: The Influence of Governments on the Court of Justice, 29 Eur. L. Rev. 3, 31 (2004) (contending that "the legitimacy of judicial decision-making is not primarily based on its representative or participatory nature, but on its certainty, finality, independence, neutrality and objectivity").

25. Joined Cases C-6/90 \& C-9/90, Francovich v. Italian Republic, 1991 E.C.R. I-5357.

26. Cf. Kilpatrick, supra note 24 , at 155 (refer ring to gender equality cases).

27. Schepel \& Blankenburg, supra note 13, at 42.

28. Cf. Kilpatrick, supra note 24 , at 144-45.

29. See infra Part II.B. 


\section{Infringement Proceedings}

The second avenue for supreme or constitutional adjudication at the EC level is the infringement action under Article 226 of the ECT. ${ }^{30}$ This type of action allows only indirectly the representation of the individual's interests before the EC courts.

According to Article 226 of the ECT, the Commission may bring Member States before the ECJ for infringement of any Treaty provision, or due to teleological interpretation, any rule of EC law. The infringement proceedings before the ECJ may be initiated only after an obligatory prelitigation procedure (letter of formal notice and reasoned opinion), during which the Commission identifies the alleged violation; the national government then has the right to reply. The Commission has full discretion as to whether and when to address to a Member State a letter of formal notice, and subsequently a reasoned opinion, under Article 226 of the ECT. In this prelitigation phase, the formal exchange of letters and memoranda is usually accompanied by negotiations. If the Member State fails to either convince the Commission of its position, or to follow the request of the Commission, the action may be brought before the ECJ. In this regard too, the Commission enjoys full discretion. ${ }^{31}$ It lodges an Article 226 of the ECT action only if and when it deems its case to be well-founded and a court action to be politically opportune.

Despite being characterized by Commission discretion, actions under Article 226 of the ECT are, from the individual's perspective, of ten a useful alternative to bringing proceedings on one's own. This is corroborated by the fact that the vast majority of infringement actions stem from complaints to the Commission filed by companies. ${ }^{32}$ Indeed, Article 226 actions have a double advantage vis-à-vis other courses of action. First, their costs are low: the costs for legal advice to draft a complaint, despite the EC specialists' fees not being cheap, remain relatively limited, and no fee is charged for the filing of the administrative complaint with the Commission. Second, the company filing a complaint, but fearing retaliation by a government or another company, may request that it remain anonymous.

30. Every Member State also has the right to bring another Member State before the ECJ. EC TrEaty art. 228. However, this action has been very rarely used.

31. See Case 48/65, Lütticke GmbH v. Commission, 1966 E.C.R. 19; Case 247/87, Star Fruit v. Commission, 1989 E.C.R. 301. See also Schermers \& WAElbroeck, supra note 1, § 1306, at 644.

32. Schepel \& Blankenburg, supra note 13 , at 15. 
However, pursuing the individual's interests through this judicial avenue has several disadvantages. First, an individual filing a complaint can never be certain that an infringement action before the ECJ will actually be brought by the Commission, which-as illustrated above-retains full discretion on the matter. Second, Article 226 judgments as such have only declaratory value. ${ }^{33}$ If the legislator remains inactive, and the national courts and administration continue to apply the "condemned" provision or behavior, the affected individuals must file an action before a national court in the hope that this court will draw from the Article 226 judgment all the desired legal consequences. It is true that in theory, national authorities may not apply "a national rule recognized as incompatible with the [EC] Treaty and, if the circumstances so require...[must] take all appropriate measures to enable Community law to be fully applied." ${ }^{4}$ But experience shows that this has often remained dead letter and that national judges tend to set aside a national provision only after a preliminary ruling to that effect. ${ }^{35}$

The limited effectiveness of Article 226 condemnations has been mitigated by two legal novelties introduced in the 1990s. First, the Maastricht Treaty introduced the possibility for the Commission to ask the ECJ to impose lump sum and daily penalties on Member States that do not comply with an ECJ ruling against them. ${ }^{36}$ This has given teeth to the Article 226 proceedings, so that often the mere threat to bring such an action suffices to convince a Member State to comply with EC law.

Second, it is easier to establish Francovich liability where the state action causing the damages has already been condemned by an Article 226 judgment. Indeed, this automatically proves the sufficiently serious character of the EC law violation, which is one of the three conditions for Francovich liability. However, the other two conditions (the infringement of an individual's right flowing from EC law and the existence of a direct causal link between the breach of the obli-

33. See EC TREATY art. 228.

34. Joined Cases 24 \& 97/80, Commission v. French Republic, 1980 E.C.R. 1333, Grounds of the Judgment, para. 16; Case 48/71, Commission v. Italian Republic, 1972 E.C.R. 527, Grounds of the Judgment, para. 7. See also Case C-101/91, Commission v. Italian Republic, 1993 E.C.R. I-191, Grounds of the Judgment, para. 24; Schermers \& WAELBroeck, supra note 1, §§ 1301-1303, at 641.

35. Cf. Rasmussen, supra note 24 , at 244.

36. EC TREATY art. 228(2). The first condemnation under this article occurred in Case C-387/97, Commission v. Hellenic Republic, 2000 E.C.R. I-5047. SChERMERs \& WAELBRoECK, supra note $1, \S$ 1298 , at 640 n.209. 
gation incumbent on the state and the loss or damage sustained by the injured parties) must also be proved, which may be very difficult. Moreover, to receive compensation for such damages, the individuals concerned must, in any event, bring an action before a national court, which is an additional burden.

These considerations illustrate the major difference between infringement rulings and preliminary rulings by the ECJ: whereas the former often do not directly entail legal consequences, the latter are usually carried out by national courts with all the authority and national law enforcement capacities that go along with a national ruling. Nonetheless, the protection, albeit indirect, of the individual's interests through the Article 226 procedure should not be downplayed. It is an important tool through which violations of the individual's EC law rights by Member States may be countervailed regardless of the existence of actions by private applicants before national courts. ${ }^{37}$

\section{B. Interest Representation through Direct Action before the EC Courts}

The second avenue for representation of the individual's interests before the EC judiciary is by direct access to the EC courts. Such access occurs through the action for annulment under Article 230(4) of the ECT, and the action for failure to act under Article 232(3) of the ECT.

Given that between these two actions, the former is in practice by far the more significant, I will focus my analysis on it. Nevertheless, it should be noted that, despite the broader wording of Article 232(3) of the ECT, the EC courts interpret the locus standi requirements and the notion of "act" under the two provisions in virtually the same way. ${ }^{38}$ Therefore, the observations that I will make about Article 230(4) of the ECT apply, mutatis mutandis, to Article 232(3) as well.

According to Article 230(4) of the ECT, any legal or natural person may, within the time limit of two months laid down in Article 230(5) of the ECT,

37. See, e.g., Case C-265/95, Commission v. French Republic, 1997 E.C.R. I-6959. In this case, the Commission succeeded in having France condemned for violation of Article 28 of the ECT (free circulation of goods) in conjunction with Article 10 of the ECT (Member States' obligation to cooperate with the EC) because it had failed to take all necessary and proportionate measures in order to prevent trucks transporting foreign goods through France from being attacked, damaged, and looted by Frenchmen on French soil.

38. See Case 247/87, Star Fruit v. Commission, 1989 E.C.R. 291, Grounds of the Judgment, para. 13 (regarding the question of locus standi under Article 232(3) of the ECT); Case 15/70, Chevalley v. Commission, 1970 E.C.R. 979, Grounds of the Judgment, para. 6 (regarding the notion of act under Article 232 of the ECT). 
challenge the legality of an EC act where either it is a decision addressed to the person or it affects him individually and directly. The notion of a challengeable act has been construed broadly to the effect of comprising all EC measures that have legal effects. ${ }^{39}$ By contrast, the EC judiciary has traditionally interpreted the notion of individual and direct concern of a nonaddressee very narrowly. In the landmark Plaumann case in 1963, the ECJ laid down a very strict test, which it has assertively confirmed in two recent judgments. ${ }^{40}$ According to this test, nonaddressees are individually concerned by an EC act only where they are affected by it by reason of certain attributes peculiar to them, or by reason of a factual situation which differentiates them from all other people, and distinguishes them individually in the same way as an addressee. ${ }^{41}$ Direct concern, in turn, essentially means that the EC measure in question can be carried out without any implementing measure. ${ }^{42}$

The Plaumann test, albeit unquestionably advantageous in many regards (such as docket control and channeling of EC litigation through national judges), also presents some problems. The main problem--simply put-is that there has been an increasing number of situations in which individuals who were not addressees were de facto affected by a given EC act, but could not challenge it under Article 230(4) of the ECT because they did not meet the Plaumann test.

Confronted with such situations, the ECJ reacted inconsistently. ${ }^{43}$ On the one hand, in some cases it denied locus standi of nonaddressees despite the tangibility of the individual interests affected. ${ }^{44}$ On these occasions, it often relied on the consideration that the contested EC measure was abstract and of general application, so that it affected the applicant in the same way as any other individual falling, actu-

39. Case C-308/95, Netherlands v. Commission, 1999 E.C.R. I-6513, Grounds of the Judgment, para. 26.

40. Case 25/62, Plaumann v. Commission, 1963 E.C.R. 95, Grounds of the Judgment, at 107. For confirmation of the Plaumann test, see Case C-50/00 P, Unión de Pequeños Agricultores v. Council, 2002 E.C.R. I-6677, Grounds of the Judgment, para. 36; Case C-263/02 P, Commission v. Jégo-Quéré (Judgment of the Court of 1 April 2004), Grounds of the Judgment, para. 45, available at http://europa.eu.inteur-lex/lex/LexUriServ/LexUriServ.do? uri=CELEX:62002J0263:EN: HTML.

41. Plaumann, 1963 E.C.R. at Grounds of the Judgment, pt. I.

42. Cf. Case 11/82, A. E. Piraiki-Patraiki v. Commission, 1985 E.C.R. 207, Grounds of the Judgment, paras. 7-10.

43. See Anthony Arnull, Private Applicants and the Action for Annulment Since Codorniu, ComMon Mкт. L. Rev. 7, 51 (2000).

44. See, e.g., Case C 97/85 R, Union Deutsche Lebensmittelwerke GmbH v. Commission, 1985 E.C.R. 1331, Grounds of the Judgment, paras. 19-21. 
ally or potentially, within the scope of application of that legislative measure. On the other hand, in other cases, the EC judges accepted locus standi of a nonaddressee by stretching the boundaries of the Plaumann test. In so doing, the ECJ had sometimes a more or less coherent strategy in mind. For example, in a series of cases the ECJ ruled that third parties enjoying the right to intervene in administrative proceedings before the Commission have locus standi to challenge the decision that is the outcome of those proceedings. ${ }^{45}$ However, the EC judges were often influenced by reasons of substantial justice strictly linked with the case at hand, and therefore their reasoning to affirm individual and direct concern was tailored to the facts of that case. An example of such reasoning is the Extramet case, in which the ECJ accepted an action brought against an antidumping regulation by a nonaddressee, because of the nonaddressee's special position on the affected market. ${ }^{46}$

From the perspective of the representation of the individual's interests, an important step taken by the ECJ was to admit that even an EC normative measure, despite its general and abstract character, may be of individual concern under Article 230(4) of the ECT ${ }^{47}$ This development of the Plaumann test allowed individuals to directly challenge EC normative acts and turned the Article 230(4) of the ECT action, to a certain limited extent, into an action enabling abstract judicial review of normative acts. However, this development has a limited reach: actions for annulment by private parties against normative acts are rarely admissible. When the applicants argued that the challengeable act applied only to them, the ECJ responded that

the possibility of determining more or less precisely the number, or even the identity, of the persons to whom a measure applies by no means implies that it must be regarded as being of individual concern to them as long as it is established that ... that application takes effect by virtue of an objective legal or factual situation defined by the measure in question. ${ }^{48}$

45. See, e.g., Case 191/82, Fediol v. Commission, 1983 E.C.R. 2913, Grounds of the Judgment, paras. 28-32.

46. Case C-358/89, Extramet v. Council, 1991 E.C.R. I-2501. See also Joined Cases T-528/93, T542/93, T-543/93 \& T-546/93, Métropole Télévision SA v. Commission, 1996 E.C.R. II-649, Grounds of the Judgment, paras. 61-64 (regarding competitors in the radio and television common markets).

47. Extramet, 1991 E.C.R. I-2501, Grounds of the Judgment, para. 13.

48. Case C-451/98, Antillean Rice Mills NV v. Council, 2001 E.C.R. I- 8949, Grounds of the Judgment, para. 52. 
The EC judiciary has not yet developed sufficiently clear guidelines as to when individuals have sufficiently peculiar characteristics to differentiate them from all others and make them subject to a normative act in the same way as if they were the addressees.

In sum, the action for annulment under Article 230(4) of the ECT makes the EC courts an administrative jurisdiction with some constitutional twists. Individuals may always bring an action for annulment against administrative acts that are addressed to them. In addition, in certain circumstances recognized by the EC judges as fulfilling the Plaumann test, individuals may challenge administrative measures that have been addressed to third parties. Exceptionally, they may also challenge normative measures. This has a number of implications with regard to the representation of the individual's interests before the EC judiciary.

First, the EC judiciary has through the years, slowly but continuously, extended the situations in which an EC measure is of direct and individual concern for an individual who is not its addressee. In particular, the question of the legality of EC normative acts may-as we have seen-be raised under exceptional circumstances directly by an individual before the EC judiciary. Because the question of when an individual may do so is very difficult and, to a certain extent, unpredictable, the challenge to normative EC acts by an individual before the EC judiciary partly depends on both the financial capacity to bear the expensive legal fees required by EC law specialists, and sheer luck-two elements that do not have much to do with equality and the rule of law.

Second, as a result of the strict Plaumann test and the resultant very limited possibility to directly challenge EC normative acts before the EC courts, the judicial review of EC acts is instead usually channeled through the Article 234 preliminary ruling procedure. Although docket-control concerns may well have played a role in Plaumann, it is submitted that they were not the main reason for this ruling. ${ }^{49}$ Rather, it must be ascribed, in the first place, to the ECJ's conscious strategy to limit the Article 230 action to a mostly administrative jurisdiction and, in the second place, to a desire to turn national courts into the day-to-day forums for the application of EC law.

If compared with the judicial review through Article 234 of the ECT, the action for annulment under Article 230 of the ECT presents certain advantages,

49. In 1963 when Plaumann was decided, the ECJ's workload sharply increased to 105 cases from 35 cases the year prior. 
but also some drawbacks. ${ }^{50}$ As illustrated above, a major advantage of Article 234 of the ECT is that it enables the ECJ to dictate the interpretation of EC law, while leaving its application to national judges. A further advantage is that the challenge to an EC normative act during proceedings before a national court entails that its judicial review is done in the context of its concrete application to a specific individual. This should enable the EC judges to make a well-informed decision in light of the social and economic circumstances of the case rather than the abstract judicial review it performs under Article 230 of the ECT. To that extent, judicial review of EC measures through Article 234 of the ECT is more effective than that provided for by Article 230(4) of the ECT.

On the other hand, in some instances the Article 230 action offers a more effective remedy, notably where time is the decisive factor. ${ }^{51}$ This is the case when negative consequences for the individuals ensue from the legal uncertainty during the pending action and the obligation in the interim to comply with the provision in question..$^{52}$ National judges may of course suspend the application of an EC act where the following three conditions are met: (1) they have serious doubts as to its validity, (2) its application would give rise to serious and irreparable damages, and (3) the Community interest in not setting aside the contested act without proper guarantees does not prevail. ${ }^{53}$ However, such interim relief, even when granted, is not always sufficient to counteract the drawbacks of a delayed judicial review. Therefore, where time is the decisive factor, challenging a measure directly before the EC courts under Article 230 of the ECT is more effective than using the Article 234 procedure. Indeed, the Article 234 procedure entails waiting for the application of the measure at issue by the national administration or private parties, so that proceedings can be instituted before a national court, which may in turn refer the question of validity to the ECJ.

50. The pleas of annulment that can be raised under Article 230 of the ECT are substantially the same as the pleas of invalidity that can be raised under Article 234 of the ECT. The same goes for the consequences that are to be drawn from annulment under Article 230 of the ECT and those flowing from a declaration of invalidity under Article 234 of the ECT.

51. See infra note 136 and accompanying text.

52. See id.

53. Joined Cases C-143/88 \& C-92/89, Zuckerfabrik Süderdithmarschen AG v. Hauptzollamt Itzehoe, 1991 E.C.R. I-415, Grounds of the Judgment, para. 33. See Schermers \& WaELBroeck, supra note $1, \S 413$, at 209. 


\section{The Reform of the EC Judicial System: New Difficulties and Opportunities for the Individual's Interest Representation Before the Courts}

\section{A. Principles Guiding the Reform}

As illustrated above, the representation of the individual's interests before the EC judiciary, despite some shortcomings and lacunae, has been successfully developed during the first fifty years of European integration. Indeed, the increased workload of the EC judiciary and its enhanced authoritativeness and political visibility are indicators of the importance and overall effectiveness of the EC remedies system. However, at present this system faces crucial new challenges. Because of the deepening and widening of European integration and because of its ever-increasing workload, the EC judiciary must be reformed in order to remain an effective vehicle for the individual's interest representation.

The debate about the reform of the EC judicial system was revived at the end of the 1990s, when the EC courts themselves issued a paper calling for such reform and setting out the various options. ${ }^{54}$ Many official statements as well as academic essays followed, presenting the most varied positions together with their pros and cons. ${ }^{55}$ Some of them have focused on the need for efficiency and docket control in the administration of justice, thereby leaving the aspect of the protection of the

54. See ECJ \& CFI, The Future of the Jurisdictional System of the European Union, at 24-31 (1999) [hereinafter The Future of the Jurisdictional System].

55. See, e.g., Anthony Arnull, The European Union and its Court of Justice (1999); Josef Azizi, Die Institutionenreform in der EU aus der Sicht der Gerichtsbarkeit, in Paradigmenwechsel im Europarecht zur Jahrtausendwende 181 (Waldemar Hummer ed., 2004); Bericht der Reflexionsgruppe über die Zukunft des Gerichtssystems der Europäischen Gemeinschaften [Report of Reflection Group on the Future of the Court System of the European Communities], NeuE Juristische Wochenschrift \& Europäische Zeitschrift für Wirtschaftsrecht [New Legal Weekly Revue and European Magazine For Commercial Law] 6 (2000), Sonderbeilage [Special Edition], available at $\mathrm{http} / /$ europa.eu.int/comm/dgs/legal_service/docs/due_de.pdf; José Luìs Da Cruz Vilaça, La Nouvelle Architecture Judiciare Européenne et la Conférence Intergouvernementale, 1-2 Cahiers de Droit Européen 3, 4 (1996); Manfred A. Dauses, Empfiehlt es sich, das System des Rechtsschutzes und der Gerichtsbarkeit in der Europäischen Gemeinschaft, insbesondere die Aufgaben der Gemeinschaftsgerichte und der nationalen Gerichte, weiterzuentwickeln?, Ständige Deputation des deutschen Juristentages [Permanent Secretariat of the German Lawyer Meeting], Verhandlungen des sechzigsten deutschen Juristentages [Reports of the 60th German lawyer meeting], vol. I, pt. D, at 121-25, 129-35, 147-62 (1994); Ulrich Everling, The Future of the European Judiciary Within the Enlarged European Union, in Mélanges en Hommage à Michel Waelbroeck 333, 
individual's interests in a secondary position. Some commentators have, of course, also focused on the protection of the individual's rights, but they have tended to do so from the standpoint of the "traditional" conception of judicial remedies as tools for the protection rather than the functional representation of the individual's interests. Therefore, the need arises to reconsider that debate from the perspective of the functional representation of the individual's interests. This need is made more urgent by the increasing development of European integration, in particular, the process of formal constitutionalization initiated by the Convention.

Before entering into the details of the proposals for reform, it is necessary to outline the principles that must guide the legislator in reforming the EC remedies system.

\section{Access to the Courts}

The access of individuals to the EC courts must be guaranteed in all cases where their interests are considerably at stake. ${ }^{56}$ As the ECJ stated in UPA:

[I]ndividuals are [ ] entitled to effective judicial protection of the rights they derive from the Community legal order, and the right

341-54 (Marianne Dony ed., 1999); Waltraud Hakenberg, Vorschläge zur Reform des Europäischen Gerichtssystems [Suggestions on the Reform of the European Court System], ZeITschrift Für Europäisches Privatrecht [Magazine for European Private Law], Apr. 2000, at 860, 862-72; Francis Hamon, La réforme du système juridictionnel communautaire, RecueIL. Dalloz, Jan. 9, 1997, at 7, 7-10; Rodol phe Muñoz, Le système de juge unique pour le règlement d'un problème multiple: l'encombrement de la Cour de justice des communautés européennes et du Tribunal de première instance, 444 Revue du Marché Commun Européen 60, 64-66 (2001); Hans-Jürgen Rabe, Zur Reform des Gerichtssystems der Europäischen Gemeinschaften, 35 Europarecht 811, 815 (2000); Hjalte Rasmussen, Docket Control Mechanisms, the EC Court and the Preliminary References Procedure, in Article 177 References to the European Court-Policy and Practice 83, 100-02 (Mads Andenas ed., 1994); Hjalte Rasmussen, Remedying the Crumbling EC Judicial System, 37 Common Mкт. L. Rev. 1071, 1077-1112 (2000) [hereinafter Remedying the Crumbling EC Judicial System]; Hannes Rösler, Zur Zukunft des Gerichtssystems der EU, Entwicklungstendenzen des EuGH zum Supreme Court Europas, Zeitschrift für Rechtspolitik, Feb. 2000, at 52,53-57; David W. Scorey, $A$ New Model for the Communities' Judicial Architecture in the New Union, 21 Eur. L. Rev. 224, 22631 (1996); Sarah E. Strasser, Evolution \& Effort: The Development of a Strategy of Docket Control for the European Court of Justice \& The Question of Preliminary References, at 29-77 (Jean Monnet Ctr. for Int'l \& Reg'l Econ. L. \& Justice, N.Y.U. Sch. of L., Jean Monnet Working Paper No. 03/95, 1995), available at http://www.jeanmonnetprogram.org/papers/95/9503ind.html; Catherine Turner \& Rodolphe Muñoz, Revising the Judicial Architecture of the European Union, 19 Y.B. Eur. L. 1, 36-40, 52-93 (Piet Eeckhout \& Takis Tridimas eds., 1999-2000).

56. Cf. SweEt, supra note 16 , at 151. 
to such protection is one of the general principles of law stemming from the constitutional traditions common to the Member States. That right has also been enshrined in Articles 6 and 13 of the European Convention for the Protection of Human Rights and Fundamental Freedoms.... 57

\section{Clarity with Regard to the Criteria for Admissibility}

Individuals must be able to find out with relative ease the conditions that they have to fulfill in order to have access to the EC courts. Consequently, these conditions must be clearly spelled out and drafted in such a way as to reduce any possible doubts about their interpretation to a minimum. This is required by the rule of law and legal certainty, which constitute principles of EC law. ${ }^{58}$

\section{Reasonable Duration of Proceedings}

The representation of the individual's interests before the EC courts can be effective only if the rulings are delivered within a reasonable time period. ${ }^{59}$ The reason for this is not only that justice delayed is justice denied. ${ }^{60}$ It also lies with the need to ensure that the interests represented before the EC judiciary are quite varied. In this context it should be borne in mind that lengthy waiting periods would discourage potential litigants from bringing an action before the EC courts. They would also reduce the willingness of national judges to refer a question to the ECJ under Article 234 of the ECT. ${ }^{61}$

57. Case C-50/00 P, Unión de Pequeños Agricultores v. Council, 2002 E.C.R. I-6677, Grounds of the Judgment, para. 39; see also Treaty Establishing a Constitution for Europe, Dec. 16, 2004, O.J. (C 310/52) art. II-107 (2004).

58. See Case 294/83, Parti Écologiste "Les Verts" v. European Parliament, 1986 E.C.R. 1339, Grounds of the Judgment, para. 23 (regarding the rule of law); Joined Cases 205 to 215/82, Deutsche Milchkontor GmbH v. Germany, 1983 E.C.R. 2633, Grounds of the Judgment, para. 30 (regarding legal certainty).

59. Convention for the Protection of Human Rights and Fundamental Freedoms, Nov. 4, 1950, art. 6, E.T.S. No. 5; see also Treaty Establishing a Constitution for Europe, supra note 57, art. II-47.

60. Cf. Case C-185/95 P, Baustahlgewebe GmbH v. Commission, 1998 E.C.R. I-8417, Grounds of the Judgment, para. 21, whereby everybody has the right to a process within a reasonable time. See also Everling, supra note 55, at 335; Göttingen von Volker Schlette, Der Anspruch auf Rechtsschutz Innerhalb Angemessener Frist-Ein Neues Prozeßgrundrecht auf EG-Ebene, EuropäIsche Grundrechte-Zeitschrift, July 30, 1999, at 369.

61. See Remedying the Crumbling EC Judicial System, supra note 55, at 1092; Strasser, supra note 55; Reimer Voss, The National Perception of the Court of First Instance and the European Court of 


\section{Docket Control}

It follows from the need for judgments within a reasonable time period that the dockets of the EC courts must be kept under control. Docket control exists where the judicial input (i.e., the newly introduced cases) is more or less equivalent to the judicial output (i.e., the issued rulings). If, as is currently the case, the former outweighs the latter, there are two ways to achieve docket control: either increase judicial output or reduce judicial input.

An increase in output is feasible only to a certain extent because both the number of judges and the speed with which cases are disposed of may be increased only in a limited way. Indeed, the number of judges composing a supreme or constitutional court such as the ECJ can be augmented only to a very limited extent. The number of judges at the Court of First Instance (CFI) may be augmented to a larger extent, but only up to a certain point if a minimal degree of coherence within the case law is to be ensured. ${ }^{62}$

By the same token, the output capacity of any court can be increased only up to a certain threshold, otherwise the quality of the rulings would suffer. Indeed, if judges do not have sufficient time for the proper handling of a case, there is a considerable risk of having a ruling that is unconvincing or in conflict with other case law. This would be fatal not only for the effective representation of the individual's interests, but also for the rule of law.

Moreover, the quantity of new rulings by a supreme or constitutional court that the legal community (other judges, legislatures, practicing lawyers, administration officials, in-house counsel) can digest is limited. ${ }^{63}$ At the same time, procedural simplifications and shortcuts offer a solution, yet only a partial one,

Justice, 30 Common Mкт. L. Rev. 1119, 1124 (1993). Cf. B.H. ter Kuile, To Refer or Not to Refer: About the Last Paragraph of Article 177 of the EC Treaty, in Institutional Dynamics of European Integration: Essays in Honour of Henry G. Schermers 381, 383 (Deirdre Curtin \& Tom Heukels eds., 1994).

62. The CFI is the second tier of the EC Judiciary which, like the ECJ, has the task of ensuring the correct interpretation and application of EC law. The CFI is competent at first instance for: (1) direct actions brought by a Member State against the Commission (except for actions for which competence is reserved for the ECJ) and certain acts of the Council, and (2) direct actions brought by individuals or undertakings against one of the $\mathrm{EC}$ institutions.

63. See Jean Paul Jacqué \& Joseph H.H. Weiler, On the Road to European Union-A New Judicial Architecture: An Agenda for the Intergovernmental Conference, 27 Coмmon Mкт. L. Rev. 185, 189 (1990); Journey to an Unknown Destination, supra note 12, at 441-42; The Least Dangerous Branch, supra note 12 , at 215 . 
because they are possible only to a certain extent; otherwise, the underlying procedural guarantees would be deprived of their content.

These considerations demonstrate that structural or major docket control problems can be solved only by limiting the number of incoming cases. Currently, the docket control problems of the EC courts are not major, but may become so in the future, given the enlargement to twenty-five Member States, the increasing number of competences of the EC judiciary, ${ }^{64}$ and the general social tendency to litigate more and more. In any event, the docket control problems of the EC judiciary are already structural: almost every year the number of solved cases outweighs, albeit by a limited quantity, the number of incoming cases. ${ }^{65}$ If this trend does not change, the result in the long term will be that the docket of the EC courts will get slowly but inevitably out of control.

From the foregoing it follows that measures must be taken to keep the judicial input of the EC courts under control. This conclusion applies in the first place to preliminary rulings under Article 234 of the ECT. It must also be kept in mind when discussing the reform of Article 230(4) of the ECT, given that an opening of the floodgates for the actions for annulment by private applicants would render the system unsustainable.

\section{Broad Spectrum of the Individual's Interests}

Finally, the functional representation of the individual's interests can be best achieved if a broad spectrum of interests is submitted to the EC courts, so that all or at least most of the crucial issues that concern every field are the object of litigation. Where the conditions for admissibility of judicial proceedings are broad and the judicial input does not outweigh the judicial output, the variety of the individual's interests submitted to the courts would probably follow naturally from the fact that such interests are widespread in society. However, where the judicial input outweighs the judicial output (as is the case with regard to preliminary rulings), it is necessary to limit the judicial input. Under these circumstances, the variety of the individual's interests must be guaranteed through specific mechanisms.

It is in accordance with these five principles that the question of the reform of the EC remedies system should be addressed. This will be done in the following paragraphs.

64. For example, under Article 229(a) of the ECT, the EC judiciary will have the power to hear direct actions in the field of industrial property rights.

65. See ECJ \& CFI Ann. Rep. 215 (2003). 


\section{B. Reform Proposals Regarding Article 234 of the ECT}

Given the increasing number of references each year, the Article 234 procedure needs to be reformed in order to keep the docket of preliminary references under control. At the same time, such reform must be drafted carefully because Article 234 of the ECT has been the cornerstone of European legal integration and, in particular, the foremost avenue for the representation of the individual's interests before the EC judiciary.

\section{Different Treatment of Preliminary References According to Their}

\section{Importance}

An appropriate way to keep the number of preliminary references under control is to treat them differently according to their importance. This means in the first place that the cases raising less relevant issues must be dealt with through a simplified procedure because it is not worth while to devote to them all the time and safeguards required when treating an important case.

This has been the spirit of some recent reforms. Under Article 104(3) of the ECJ Rules of Procedure (RP) as amended in 2000, the ECJ may answer a preliminary question by order where it is identical to a question on which the Court has already ruled, where the answer to such a question may be clearly deduced from existing case law, or where the answer to the question admits of no reasonable doubt. Besides, under the reformed Article 20 of the ECJ Statute, ${ }^{66}$ the ECJ may do without the Advocate General's opinion where it considers that the case raises no new point of law. ${ }^{67}$ Additionally, under Article 225(3) of the ECT, as amended by the Treaty of Nice, the Council may transfer the competence to answer preliminary references in certain fields from the ECJ to the CFI. The

66. Protocol on the Statute of the Court of Justice annexed to the Treaty on European Union, to the Treaty establishing the European Community and to the Treaty establishing the European Atomic Energy Community, in accordance with Article 7 of the Treaty of Nice, amending the Treaty on European Union, the Treaties establishing the European Communities and certain related acts, signed at Nice on 26 February 2001, 2001 O.J. (C 80) (Mar. 10, 2001), as amended by Council decision of 15 July 2003 amending Article 23 of the Protocol on the Statute of the Court of Justice, 2003 O.J. (L 188) (July 26, 2003); Council Decision of 19 April 2004 amending Articles 16 and 17 of the Protocol on the Statute of the Court of Justice, 2004 O.J. (L 132); and Council Decision of 26 April 2004 amending Articles 51 and 54 of the Protocol on the Statute of the Court of Justice, 2004 O.J. (L 132).

67. The Advocate General has the task of presenting, with impartiality and independence, a reasoned opinion to assist the judges in deciding the case. 
Council, however, has not yet made use of this power. Finally, an additional EC court in charge of staff cases has been set up pursuant to Articles 220 and 225a, which provide for the creation of judicial panels in certain specific areas. ${ }^{68}$

On the whole, these reforms appear both useful and appropriate. Yet, they do not suffice to ensure the effectiveness and efficiency of the preliminary reference procedure in the long run. To attain this aim it is necessary to go further.

My main reform proposal regarding the preliminary ruling procedure is to amend the ECJ Statute and the RP to treat preliminary references differently according to the group within which they fall. The relevant groups should be as follows:

(1) references that, in consideration of the importance of the case, raise a fundamental legal question or that might endanger the uniformity and coherence of EC law;

(2) references that raise no fundamental question of EC law and to which the referring judge has proposed a wrong answer;

(3) references that raise no fundamental question of EC law and to which the referring judge proposes an answer that is substantially correct.

Given their different characteristics, it is not necessary for references falling within different groups to be treated in the same manner. Indeed, the references in the first group, given their importance, must be dealt with by the ECJ with all the full procedural features such as a sufficient number of judges and the opinion of the Advocate General.

The references in the second group can be answered more easily. Therefore, they do not require the intervention of a supreme or constitutional court such as the ECJ, which should concentrate its efforts on fundamental questions of EC law. Thus, the references of the second group should be dealt with by the CFI, which for this purpose should be enlarged and equipped with Advocates General.

The new Article 225(3), as illustrated above, provides that the Council may, in certain areas, transfer the competence for preliminary rulings from the ECJ to the CFI. A part from its merely programmatic content, this provision is a welcome development, given that the CFI has an expertise in technical areas such as competition (including state aid), customs, antidumping, and trademarks. However,

68. See Council Decision 2004/752 of 2 November 2004 establishing the European Union Civil Service Tribunal, O.J. (L 333) 7 (2004). 
the ratione materiae criterion provided for in Article 225(3), if not supplemented with further criteria, appears only partially satisfactory. Indeed, important questions can be raised in any area. It is true that under Article 225(3) the CFI may refer the case to the ECJ where it considers that it requires a decision of principle likely to affect the unity or consistency of Community law. However, this mechanism is insufficient because it simply allows, but does not oblige, the CFI to refer the case to the ECJ. ${ }^{69}$ Indeed, a judge who has invested time in a case is unlikely to spontaneously refer it to a higher judge because it is too important. All judges like to have interesting cases on their desks. Therefore, given that important questions can be raised in any field, it is necessary that preliminary references are allocated between the ECJ and the CFI according to their importance after a case-by-case examination. This does not exclude the application of Article 225(3), but adds to the ratione materiae criterion an additional one based on the importance of the case.

In this context it is necessary to ask which of the two courts (ECJ or CFI) should be in charge of the allocation of the references. In a previous publication I supported the solution whereby the allocation competence should lie with the CFI. ${ }^{70}$ Now, after having reconsidered the issue, I would favor the allocation of this competence to the ECJ. It is true that procedural economy considerations militate in favor of the CFI solution, given that under the proposed reform most preliminary references, at least in some areas, will be answered in the future by the CFI. My argument ran that if the reporting judge and the Advocate General within the CFI have to reply to most preliminary references, it would make sense for them (and not their counterparts within the ECJ) to study the file in order to make a decision on the allocation.

This argument is per se correct, but not decisive. Indeed, the coherence and uniformity of EC law can be best ensured only if the competence to allocate references between the ECJ and the CFI rests with the former. The reason for this is that the ECJ, as supreme court, has the last word on the interpretation of EC law and thus is best placed to steer its development. Accordingly, it should be the Pres-

69. EC TREATY art. 225(3) ("Where the Court of First Instance considers that the case requires a decision of principle likely to affect the unity or consistency of Community law, it may refer the case to the Court of Justice for a ruling.") (emphasis added).

70. See Luigi Malferrari, Zurückweisung von Vorabentscheidungsersuchen durch den EuGH 260-61 (2003). 
ident of the ECJ, after having heard the First Advocate General, ${ }^{71}$ to decide whether to allocate a preliminary reference to the ECJ or the CFI. ${ }^{72}$

A further important and controversial question in this connection is whether the CFI preliminary rulings may be reviewed by the ECJ. An answer in the affirmative, as provided for by Article 225(2), after the amendment of the Nice Treaty, is in my view appropriate. Although an extension of the duration of proceedings is not optimal from the perspective of the effectiveness of remedies, the need to rule out the disruptive effects of "wrong" CFI judgments that would become res judicata must be given priority. Consequently, it should be provided that the President of the ECJ, after having heard the First Advocate General, may propose to the general meeting of the ECJ members to review the preliminary ruling. ${ }^{73}$ This assembly will decide whether to accept the review.

It goes without saying that review by the ECJ of CFI preliminary rulings should be possible only under exceptional circumstances, such as when:

(1) the CFI preliminary ruling raises a fundamental question of EC law;

(2) the CFI preliminary ruling is in conflict with other ECJ or CFI case law; or

(3) the CFI preliminary ruling contains a gross error.

Article 225(3), as amended by the Nice Treaty, goes in this direction by providing that CFI preliminary rulings "may exceptionally be subject to review by the Court of Justice, under the conditions and within the limits laid down by the ECJ Statute, where there is a serious risk of the unity or consistency of Community law being affected."

To minimize the duration of the proceedings, the ECJ should render its review ruling within a very strict time limit (e.g., four months). The use of the

71. The First Advocate General is chosen from among all the Advocates General and has the task of coordinating their work and allocating cases to each Advocate General.

72. The question could be raised in this context whether this rule is compatible with the principle of natural court (juge naturel) enshrined in national as well as constitutional law. Without entering into the details of the matter, I would like to point out that these doubts, albeit legitimate, are not well-founded.

73. Art. 62(1) of the ECJ Statute provides that the right to propose a review of CFI preliminary ruling lies with the First Advocate General. This solution is certainly reasonable. However, giving this power to the President appears more appropriate because doing so would render it easier to ensure coherence of EC law given that the mandate of the President is longer than the one of the First Advocate General. 
accelerated procedure provided for by RP Article 104a would be necessary in this case. ${ }^{74}$

Turning now to the preliminary questions falling within the third group, these questions do not require a full answer by the EC courts because the answer that the referring judge has proposed is substantially correct. ${ }^{75}$ Under such circumstances, the CFI should be in charge of them and can limit itself to giving the green light to the interpretative results reached by the referring judge and to issuing an order to this effect (to be called the green-light order). An open question is whether such an order would have the same value as normal preliminary rulings, that is, whether it would constitute a binding precedent for national courts. In my opinion, the necessary quickness of the green-light procedure militates in favor of a negative answer.

On the one hand, green-light orders present, of course, some shortcomings if compared with normal preliminary rulings. On the other hand, they offer a major advantage: they would allow the EC judges to confirm very quickly and effortlessly to the referring judge that the interpretation of EC law proposed is substantially correct. The green-light procedure would already today entail a more rational allocation of the time of the EC judiciary. At any rate, its introduction will become very appropriate once the workload of the EC judiciary becomes so burdensome that there will be no choice: either it must answer such simple cases by means of the green-light procedure or give them no reply at all. It is submitted that a green-light answer is better than no answer at all.

Green-light orders are somehow similar to the already existing orders under Article 104(3), by which the ECJ may also dispose quickly of easy cases. However, the former would be more advantageous because they take less time

74. The accelerated procedure is applied where the circumstances of the case establish that a ruling on the question put to the ECJ is a matter of exceptional urgency. Under the accelerated procedure, it may be derogated from the provisions of the RP regarding preliminary references. In particular, the following measures may be taken:

- the President may immediately fix the date for the hearing;

- the parties and other interested persons may lodge statements of case or written observations within a period prescribed by the President, which shall not be less than 15 days;

- the President may request the parties and other interested persons to restrict the matters addressed in their statement of case or written observations to the essential points of law raised by the question referred.

Under the accelerated procedure, the ECJ rules after hearing the Advocate General.

75. See The European Court, supra note 12, at 375-77; see also Strasser, supra note 55, at 62. 
and probably would not constitute formal precedents. Since green-light orders would represent a novelty, this instrument should be introduced by way of a Treaty amendment.

\section{Codification of the Admissibility Criteria}

The criteria for the admissibility of preliminary references have been developed by the ECJ throughout the years. Whereas during the first decades of European integration the ECJ barely examined the admissibility of preliminary references, at the end of the 1970s, spurred by the circumstances of certain specific cases, it started to develop a jurisprudential corpus of admissibility criteria under Article 234 of the ECT. ${ }^{76}$ During the 1990s, not only did this case law grow larger (albeit incoherently), but in addition, the review of admissibility of preliminary references was carried out with a tougher standard of scrutiny, resulting in an increasing number of references being rejected as inadmissible. ${ }^{77}$ Consequently, the question of knowing the exact content of the admissibility criteria under Article 234 of the ECT, and the way they are applied, has become both crucial and difficult.

The main problem created by this legal uncertainty is that a strict application of such unclear admissibility criteria may discourage national judges from making a reference to the EC courts, because they may fear both the useless delay and the embarrassment that would result from a rejection.

To remedy these problems, I propose to codify the admissibility criteria under Article 234 of the ECT in a very detailed manner. For this purpose, a sentence should be added to Article 234 of the ECT to the effect that "the conditions of admissibility of preliminary references are laid down in the Rules of Procedure." This codification in the RP would build on the admissibility criteria as developed in the case law, but would clarify their content to make them more coherent. ${ }^{78} \mathrm{It}$ should also develop some of them further to take fully into account the five above mentioned principles guiding the reform of the EC remedies system. It could in

76. See, e.g., Case 93/78, Lothar Mattheus v. Doego Fruchtimport und Tiefkühlkost eG, 1978 E.C.R. 2203, Grounds of the Judgment, para. 7; Case 105/79, Preliminary Ruling by the Acting Judge at the Tribunal d'Instance (Hayange I), 1979 E.C.R. 2257.

77. See, e.g., Joined Cases C-320/90, C-321/90 \& C-322/90, Telemarsicabruzzo SpA v. Circostel, 1993 E.C.R. I-393; Case C-83/91, Wienand Meilicke v. ADV/ORGA AG, 1992 E.C.R. I-4871; Catherine Barnard \& Eleanor Sharpston, The Changing Face of Article 177 References, Common Mkt. L. Rev. 1113 (1997); MALferRaRi, supra note 70, at 19, 31-32, 195-201, 219-20.

78. See Malferrari, supra note 70, at 229-50. 
particular be envisaged to introduce a new admissibility criterion whereby fully trivial preliminary questions are rejected. This measure, which entails a mild filtering of the preliminary references, would be appropriate when the case law grows out of proportion, unless other effective docket control mechanisms such as the green-light procedure discussed above are introduced and suffice.

The introduction of a new admissibility criterion based on the relevance of the referred question seems prima facie at odds with an effective representation of the individual's interests in the courts. Yet, as was highlighted above, at a certain point docket control problems cannot be solved by increasing judicial output, but must be tackled by reducing judicial input. In my view, this will soon be necessary for the EC judiciary, and therefore reformatory action must be taken now. It cannot be emphasized enough that under the present circumstances docket control is not only in conformity with, but is also required by an effective representation of the individual's interests in the courts because justice delayed is justice denied, and the good quality of judgments demands time. The effectiveness of the representation of the individual's interests in the courts requires that the case selection is done not randomly or on a first-come-first-served basis, but rather according to the importance of the issues raised. Only this method would ensure in the future that most of the relevant issues are the object of scrutiny by the EC judges and that the coherence and uniformity of EC law are maintained.

\section{All Areas of EU and EC Law Must Be Included Within the Scope of Application of Article 234 of the ECT}

Since the entry into force of the Treaty on European Union in 1993, a new trend regarding Article 234 of the ECT can be observed. This trend consists of excluding some primary and secondary provisions of EU or EC law from the scope of application of the preliminary ruling procedure. For the purposes of this paper, I do not need to illustrate all the details of these limitations. ${ }^{79}$ In this context I will mention only two typical examples that regard provisions of particular relevance for individuals:

- the provisions on police and judicial cooperation in criminal matters laid down in the Treaty on European Union (EUT) (Articles 29-42 of the EUT), which are excluded from the scope of application of Article 234 of the ECT;

79. See id. at $62-65$. 
- the measures enacted on the basis of Articles $29-42$ of the EUT, ${ }^{80}$ which are excluded from the scope of application of Article 234 of the ECT, unless the Member State concerned has accepted, by a declaration made at the time of signature of the Treaty of Amsterdam or at any time thereafter, the jurisdiction of the ECJ to give preliminary rulings. ${ }^{81}$

In my view, this limitation of the scope of application of Article 234 of the ECT is not justified and should be rectified. Even if its aim-and I am not sure this is the case ${ }^{82}$ - is to keep the ECJ docket under control, it is plain that other docket control mechanisms exist that would involve lesser curtailment of the effective protection of the individual's interests.

\section{The Right to Refer Should Be Given to All Courts in All Areas of EU and EC Law}

A further way to reduce the scope of application of Article 234 of the ECT is to reserve the right to make a reference to national courts against whose decisions there is no judicial remedy. The techniques employed are analogous to those used for excluding a provision from the scope of application of Article 234 of the ECT as illustrated above. First, a reference to the ECJ may (nota bene: not "must") be made only by last instance courts with regard to some EC law provisions, such as Articles 61-69 of the ECT, regarding visas, asylum, immigration, and other policies relating to the free movement of persons. Second, as regards some EC provisions such as the abovementioned measures enacted on the basis of EUT Articles in the field of police and judicial cooperation in criminal matters, it is left to the discretion of each Member State not only to decide whether to accept the application of Article 234 of the ECT, but also, if they do so, to determine which courts may apply Article 234 of the ECT.

Even before these Treaty amendments, the limitation of the right to refer to last instance courts had been envisaged in academic and institutional circles as a

80. Framework decisions, decisions, conventions, and measures implementing them in the sense of Article 34 of the Treaty on European Union, O.J. (C 191) (1992) [hereinafter Treaty on European Union].

81. Treaty on European Union art. 35. It should be noted that under this provision only, the interpretation of conventions enacted on the basis of Article 34 of the EUT may be the object of a preliminary reference.

82. See Paolo Biavati \& Federico Carpi, Diritto Processuale Comunitario 427-32 (2000); Oliver Dörr \& Ute Mager, Rechtswahrung und Rechtsschutz nach Amsterdam-Zu den Neuen Zuständigkeiten des EuGH, 125 Archiv des ÖfFentuichen Rechts 386, 425-26 (2000). 
tool for keeping the ECJ docket under control.$^{83}$ Indeed, the docket control effects of this limitation cannot be denied. However, I have some doubt about its appropriateness. In fact, the development of EC case law shows irrefutably that the preliminary questions referred by first- and second-instance courts are not necessarily less relevant than those posed by last-instance courts. ${ }^{84}$ If we take into consideration that in some pivotal cases such as Francovich and Costa/ENEL, the preliminary question was referred by a first-instance judge, whereas the court of last instance would have been reluctant to make a reference, it becomes clear that the discussed limitation of the right to refer entails negative consequences for the effectiveness of the representation of the individual's interests. This is aggravated by the fact that the abovementioned provisions lay down the right, but not the obligation to refer by last-instance courts. If docket control were the aim of those provisions (and here it may well have been the case), it is submitted that other devices would have attained the same result in terms of reduced judicial input, but would at the same time have better preserved the effectiveness of the protection of the individual's interests by way of Article 234 of the ECT.

\section{Should Individuals Have the Right to Appeal National Rulings before the EC Judiciary?}

There have been proposals to introduce the possibility for an individual to challenge a national last-instance ruling applying EC law before the EC judiciary, given that an individual may not oblige a national judge (not even of last instance) to refer a question to the ECJ. ${ }^{85}$ This reform would indeed solve many problems in furtherance of an effective protection of the individual's interests. In particular, it would remedy the situation where a last-instance court fails to refer a relevant EC law question to the ECJ, even though it is obliged to do so under

83. Rasmussen, supra note 24, at 1104-07. Cf. Volker Lipp, Entwicklung und Zukunft der Europäischen Gerichtsbarkeit, 52 Juristen Zeirung 326, 331-32 (1997); Klaus Peter Müller-Eiselt, Trendwende beim Vorabentscheidungsverfahren (Art. 177 EGV)?, 12 ZEITsChrifT Für ZöLl.E und VerbRAUCHSTEUERN 414, 418 (1997).

84. See Case 6/64, Flaminio Costa v. ENEL, 1964 E.C.R. 585; Joined Cases C-6/90 \& C-9/90, Andrea Francovich v. Italian Republic, 1991 E.C.R. 5357. These two cases are famous examples of references made by first instance courts. See Case C-415/93, Union Royale Belge des Sociétés de Football Ass'n ASBL v. Jean-Marc Bosman, 1995 E.C.R. I-4921 (a famous example of reference made by a second instance court).

85. See Baquero Cruz, La procédure préjudicielle suffit-elle à garantir l'efficacité et l'uniformité du droit de l'Union européenne?, in L'AUTORITÉ DE L'UNion EUROPÉENNE (Loïc Azoulai \& Laurence Burgorgue-Larsen eds., forthcoming 2005). Cf. The Future of the Jurisdictional System, supra note 54. 
Article 234(3) of the ECT. Even if this reform brings with it the risk of generating many more cases than the EC courts could sustain, strict admissibility criteria (such as the requirement that the appealed judgment could subvert the unity or coherence of EC law) may reduce this risk to a minimum.

In my opinion, however, there is an argument that militates decisively against the immediate introduction of this reform. Until now the application of EC law in the Community has been entrusted to national judges. An EC quasi-federal judiciary spread out in all the Member States, as is present in the United States, has not been created. This choice has some drawbacks, but certainly many advantages, the greatest of them being that national judges have given to EC law the formal authority and enforcement mechanisms typical of national law. It is submitted that as long as the process of formal constitutionalization of the EC legal order and its acceptance do not advance considerably, the time is not ripe for such a reform that would revolutionize the relationship of cooperation between national courts and the EC courts, which is one of the pillars of the Community legal order. EC law operates as if it were the supreme law of the land in each Member State, but formally it is not. This ambivalence is not necessarily detrimental-quite the oppositebecause it reflects the fact that sovereignty is divided between the Community and the Member States. The envisaged reform would instead solve this question in favor of the EC, by introducing an overtly hierarchical and federal element that might exacerbate the latent tensions that already inevitably exist between the Community and the Member States due to the sharing of sovereignty.

\section{Reform Proposals Regarding Article 226 of the ECT}

Article 226 of the ECT, after the reforms of the 1990s, has now been revitalized, demonstrating the ability to play a renewed and important role in the EC constitutional game. Still, two reforms may yet be necessary, in order to enhance the ability of individuals to induce the Commission to bring Article 226 actions against Member States violating EC law to their detriment.

First, the Treaty should be amended to state more clearly the obligation on all state authorities ensuing from a condemnation under Article 226 of the ECT. Article 228(1) of the ECT is currently worded as follows: "If the Court of Justice finds that a Member State has failed to fulfill an obligation under this Treaty, the State shall be required to take the necessary measures to comply with the judgment of the Court of Justice." A second sentence should be added to the effect that: 
In particular all national legislative bodies, administrative authorities and members of the judiciary should draw all the necessary legal consequences from the condemnation under Article 226, including setting aside national rules and practices regarded by the ECJ as incompatible with the Treaty and interpreting national law in a way as to afford full effect to EC law.

Second, the Commission's discretion as to whether to bring an action under Article 226 of the ECT should be limited. If the Commission does not want to initiate the prelitigation procedure, or fails to take the Member State to court, or eventually drops the case after proceedings have been instituted, it must provide sufficient reasoning for its decision, so that the complainants concerned-if any-may contest the Commission's decision before the court. The Commission's decision remains discretionary, but it cannot be arbitrary. To control this, it must be motivated and must be challengeable under Article 230(4) of the ECT.

\section{Reform Proposals Regarding Article 230(4) of the ECT}

\section{Better, Not Broader, Admissibility Criteria are Needed}

In contrast with Article 234 of the ECT, Article 230(4) of the ECT has often been criticized for laying down unduly strict conditions for admissibility. However, in my view the central problem is not the strictness of the conditions for standing of individuals under Article 230(4) of the ECT, but the results they yield. As was underlined above, the Plaumann test does not satisfactorily allow access to the court in two regards. First, the admissibility criteria must be inferred from the relevant case law, which is complex, incoherent, and case-bycase oriented, with detrimental results for legal certainty and the rule of law. Second, there are situations where, although the individual's interests are considerably at stake and a direct action would be necessary to ensure effective judicial protection, the strict Plaumann test is not met, so that the affected person does not have locus standi under Article 230(4) of the ECT.

From the foregoing it is clear that the action for annulment by private applicants needs to be reformed. The main problems ensue from the strict notion of individual concern under Article 230(4) of the ECT, and therefore I will focus here on that aspect only. The central question in this context is how to conciliate in the best possible way the two main principles mentioned above: access to the courts 
and docket control. For this purpose, certain constraints cannot be disregarded. First, the workload of the EC judiciary, including the CFI, which is in charge of dealing with annulment actions by private parties, is already quite burdensome. As explained above, in the EC, judicial output can be augmented only to a limited extent. Therefore, even if the EC judiciary-especially after being invigorated through the introduction of judicial panels ${ }^{86}$ and improved rules of procedurecould sustain a higher number of direct actions for annulment by individuals, this number could certainly not be raised considerably. Otherwise waiting periods would be too long and the quality of judgments might decline, with all the negative consequences already outlined above. Consequently, the reform of Article 230(4) of the ECT should aim at improving the admissibility criteria to afford clear and effective judicial protection wherever it is definitely needed (the principle of access to court), but in such a way that the number of admissible actions does not rise considerably (the principle of docket control).

\section{Advocate General Jacobs's Proposed Reform in UPA}

Recently, the effort to change the law on locus standi under Article 230(4) of the ECT has come from within the EC judiciary itself. The first attempt has been performed by Advocate General Francis Jacobs in his opinion in UPA. ${ }^{87} \mathrm{In}$ this case an association of Spanish farmers challenged an EC regulation which substantially amended the common organization of the olive oil market. ${ }^{88} \mathrm{Ad}$ vocate General Jacobs proposed a new interpretation of the notion of "individual concern" under Article 230(4) of the ECT whereby a person is "individually concerned by a Community measure where, by reason of his particular circumstances, the measure has, or is liable to have, a substantial adverse effect on his interests." 89

Advocate General Jacobs came to this conclusion by deeming the Plaumann test incompatible with the principle of effective judicial protection..$^{90} \mathrm{He}$ argued first that national proceedings "do not...always provide effective judicial protection." ${ }^{11}$ He thereby relied on a number of reasons which can be summarized

86. See EC TREaty art. 225(a).

87. Case C-50/00 P, Unión de Pequeños Agricultores v. Council, 2002 E.C.R. I-6677, Opinion of the Advocate General.

88. Id. at Grounds of the Judgment, paras. 1-3.

89. Id. at Opinion of the Advocate General, para. 60.

90. Id. paras. 4, 59-65.

91. Id. para. 37. 
as follows: (1) national courts may only assess whether a party's doubts about the validity of an EC measure are sufficient; (2) individuals do not have a right to refer a question under Article 234 of the ECT; (3) national courts may not declare EC measures invalid; (4) interim relief depends to some extent on the discretion of the national judge and, even where given, is limited to the Member State of that judge; (5) in some cases there is no national implementing measure that can be challenged before national courts; and (6) national proceedings entail additional delay and costs. ${ }^{92}$

Second, Advocate General Jacobs argued that a direct action under Article 230 of the ECT is "more appropriate for determining issues of validity than reference proceedings under Art. 234 EC. ${ }^{13}$ He substantiated this statement by underlining the following elements: the institution that has adopted the contested measure may be part of the proceedings under Article 230; third parties may intervene in a very simple manner in Article 230 proceedings, ${ }^{94}$ whereas under Article 234 of the ECT they may intervene before the ECJ only if they are parties to the main proceedings before the referring judge; direct actions allow a full exchange of views (application, defense, reply, rejoinder); interim relief granted by the EC judges is effective in all Member States; and from the viewpoint of legal certainty it is desirable to resolve the question of validity of measures of general application as soon as possible. ${ }^{95}$

Advocate General Jacobs's proposal is very interesting and, in several regards, convincing. His proposed new test could be partially retained, at least for some purposes. However, some of his arguments do not appear fully compelling. For example, the statement whereby a general EC measure can be reviewed more effectively via Article 230 of the ECT rather than Article 234 of the ECT is not compelling because, in my opinion, a general measure is usually better reviewed if applied to a specific case, and thus put in its socioeconomic context.

Furthermore, the fact that individuals must wait for a national measure implementing the $\mathrm{EC}$ normative act in question does not necessarily render Article

92. Id. paras. $38-44$.

93. Id. para. 45.

94. To intervene, an individual must show an "actual" interest in the relief that would directly ensue from the result of the dispute. See Joined Cases C-151/97 \& 157/91 P(I), National Power plc v. British Coal, 1997 E.C.R. I-3491; Case 111/63, Lemmerz-Werke GmbH v. High Authority of the ECSC, 1965 E.C.R. 716; Joined Cases T-97/92 \& T-111/92, Loek Rijnoudt v. Commission, 1993 E.C.R. II-587, Grounds of the Judgment, para. 22.

95. Unión de Pequeños Agricultores, 2002 E.C.R. I-6677 at Opinion of the Advocate General, paras. $46-49$. 
230 of the ECT more effective, because such a measure usually follows, or can be provoked, and thus can be challenged before national courts, which may then refer to the ECJ the question of the validity of the original EC normative act. ${ }^{96}$ Some legal systems, such as those of Germany, Belgium, and Italy, provide for declaratory actions so that judicial proceedings may be instituted without a national implementing measure.

Moreover, Advocate General Jacobs does not consider the importance of Article 234 of the ECT as a tool for favoring the application of EC law throughout the Community. Further, the view that there is no risk of a deluge of cases because the other admissibility conditions (direct concern, the two-month time limit, and the interest in bringing proceedings) would limit the number of actions appears to be rather optimistic. ${ }^{97}$

In addition, I have some doubts about the proposition whereby the fact that a measure adversely affects a large number of individuals provides a reason for accepting a direct challenge by one or more of those individuals. ${ }^{98}$ This approach is, in my view, not in line with the idea of individual concern contained in Article 230(4) of the ECT, the text of which does not appear to allow for the invocation of an actio popularis.

Finally, Advocate General Jacobs's criteria do not seem to include circumstances in which locus standi is given under Plaumann, such as a violation of procedural rights or a violation of the institution's obligation to take the applicants' position into consideration. ${ }^{99}$

\section{The CFI's Proposed Revolution in Jégo-Quéré}

The second recent attempt to change the Plaumann test has been made by the CFI with its judgment in Jégo-Quéré. ${ }^{100}$ In this case a fishing company brought an action for annulment against an EC regulation prohibiting the use of mesh size smaller than $100 \mathrm{~mm} .{ }^{101}$ After having assessed that the applicant did

96. But see id. para. 43; Case T-177/01, Jégo-Quéré v. Commission, 2002 E.C.R. II-2365, Grounds of the Judgment, para. 45.

97. See Unión de Pequeños Agricultores, 2002 E.C.R. I-6677 at Opinion of the Advocate General, para. 79.

98. See id. para. 59.

99. See Luigi Malferrari \& Christoph Lerche, Zulässigkeit der Nichtigkeitsklage von Privatpersonen nach Art. 230 EG-Niedergang und Wiederaufleben des Plaumann-Tests, in EuropäIsches WirTsChaftS-und Steuerrecht 254, 260 (2003).

100. Jégo-Quéré, 2002 E.C.R. II-2365.

101. Id. at Grounds of the Judgment, paras. 3-6. 
not satisfy the Plaumann test, the CFI analyzed the question of whether the inadmissibility of the action would deprive the applicant of the right to an effective remedy as laid down in EC law. ${ }^{102}$

The CFI answered this question in the affirmative. In the first place, it ruled out that in the case before it, Article 234 of the ECT would be an effective remedy because the contested regulation does not provide for the adoption of any national implementing measure that could be challenged before national courts. ${ }^{103}$ Along with Advocate General Jacobs's opinion, it held:

The fact that an individual affected by a Community measure may be able to bring its validity before the national courts by violating the rules it lays down and then asserting their illegality in subsequent judicial proceedings brought against him does not constitute an adequate means of judicial protection. Individuals cannot be required to breach the law in order to gain access to justice. ${ }^{104}$

In the second place, the CFI did not accept that the noncontractual liability action under Article 288 of the ECT provided satisfactory judicial protection. ${ }^{105}$ Indeed, the CFI stated that this action cannot result in the removal from the Community legal order of the contested measure; moreover, it is "subject to criteria of admissibility and substance which are different from those governing actions for annulment"-in particular, the review carried out of legislative acts is limited "to the censuring of sufficiently serious infringements of rules of law intended to confer rights on individuals." 106

The CFI thereby came to the conclusion that the judicial remedies provided for by the Treaty do not provide the applicant with an effective remedy to contest the legality of an EC measure of general application. ${ }^{107}$ For this reason, the CFI reconsidered the notion of individual concern under Article 230(4) of the ECT. ${ }^{108}$ It thus held:

102. Id. paras. 41-43.

103. Id. para. 45 .

104. Id.

105. Id. para. 46.

106. Id.

107. Id. para. 47

108. Id. paras. $49-50$. 
[I]n order to ensure effective judicial protection for individuals, a natural or legal person is to be regarded as individually concerned by a Community measure of general application that concerns him directly if the measure in question affects his legal position, in a manner which is both definite and immediate, by restricting his rights or by imposing obligations on him. The number and position of other persons who are likewise affected by the measure, or who may be so, are of no relevance in that regard. ${ }^{109}$

The CFI's approach is to be welcomed to the extent that it considerably contributed to the debate on the admissibility of actions for annulment by private parties. On the other hand, both the reasoning and the new test proposed by the CFI leave certain questions unresolved.

As to its line of reasoning, the CFI deems that Article 234 of the ECT is an ineffective remedy because the contested regulation does not provide for the adoption of any national implementing measure that could be challenged before national courts. As explained above in regard to Advocate General Jacobs's opinion, this assertion is only partially convincing. Even if the contested regulation does not provide for the adoption of any measure that could be challenged before national courts, the possibility for the individual to institute proceedings before national courts is by no means excluded. Indeed, national procedural law may provide for declaratory actions that are admissible against a measure regardless of its application. Moreover, under national law the enterprise may be able to require the administration to issue a declaratory statement as to the applicability of the contested measure to it; this measure could in turn be challenged before national courts. Therefore, unless the CFI wants to examine and interpret in detail national procedural rules (which it is not permitted to do), it is not true-as the CFI implies-that individuals such as Jégo-Quéré must break the law in order to gain access to justice against measures such as the contested regulation. ${ }^{110}$

Besides, there is the risk that the proposed new test is incoherent to the extent that it deprives the notion of individual concern under Article 230(4) of the ECT

109. Id. para. 51.

110. See also Case C-50/00 P, Unión de Pequeños Agricultores v. Council, 2002 E.C.R. I-6677, Grounds of the Judgment, para. 43; Opinion of the Advocate General, paras. 51-60. 
of its meaning. ${ }^{111}$ Indeed, it requires only a definite and immediate restriction of the applicants' rights or an imposition on them of duties, without taking into account the number and position of other persons who are similarly affected by the measure. As Anthony Arnull elegantly put it, "if it is to be meaningful, the requirement of individual concern will inevitably require an applicant to show a real difference, in qualitative or quantitative terms, between the repercussions for it of the disputed measure and its repercussions for other people affected by it." 112

\section{The ECJ's Counterrevolution}

In its judgments in UPA and Jégo-Quéré, the ECJ rejected both proposed tests and confirmed the Plaumann test. The ECJ recognized that under EC law, "individuals... are entitled to effective judicial protection." ${ }^{13}$ It acknowledged that "the Treaty has established a complete system of legal remedies and procedures designed to ensure judicial review of the legality" of EC measures. ${ }^{114}$ The ECJ rejected, however, the argument that locus standi should be granted where, under national law, the applicant may not bring proceedings to contest the validity of the EC measure at issue. The ECJ correctly observed: "Such an interpretation would require the Community Court, in each individual case, to examine and interpret national procedural law. That would go beyond its jurisdiction when reviewing the legality of Community measures." 115 The ECJ conceded that the requirement of a direct and individual concern "must be interpreted in the light of the principle of effective judicial protection by taking account of the various circumstances that may distinguish an applicant individually." 116 It thereby referred to borderline cases such as Van der Kooy, Extramet, and Codorniu, in which locus standi had been exceptionally recognized. ${ }^{117}$ At the same time,

111. See Case C-263/02 P, Commission v. Jégo-Quéré (Judgment of the Court of 1 April 2004), Grounds of the Judgment, para. 38, available at http:/europa.eu.int/eur-lex/lex/LexUriServ/ LexUriServ.do? uri =CELEX:62002J0263:EN:HTML.

112. Arnull, supra note 43, at 40-41.

113. Unión de Pequeños Agricultores, 2002 E.C.R. 1-6677 at Grounds of the Judgment, para. 39; see also Jégo-Quéré (Judgment of the Court of 1 April 2004) at Grounds of the Judgment, para. 29.

114. Unión de Pequeños Agricultores, 2002 E.C.R. I-6677 at Grounds of the Judgment, para. 40; see also Jégo-Quéré (Judgment of the Court of 1 April 2004) at Grounds of the Judgment, para. 30.

115. Unión de Pequeños Agricultores, 2002 E.C.R. I-6677 at Grounds of the Judgment, para. 43; Jégo-Quéré (Judgment of the Court of 1 April 2004) at Grounds of the Judgment, para. 33.

116. Unión de Pequeños Agricultores, 2002 E.C.R. I-6677 at Grounds of the Judgment, para. 44; Jégo-Quéré (Judgment of the Court of 1 April 2004) at Grounds of the Judgment, para. 36.

117. Unión de Pequeños Agricultores, 2002 E.C.R. I-6677 at Grounds of the Judgment, para. 44. 
the ECJ stressed that "such an interpretation cannot have the effect of setting aside the condition in question, expressly laid down in the Treaty, without going beyond the jurisdiction conferred by the Treaty on the Community Courts." 118 The ECJ concluded:

While it is, admittedly, possible to envisage a system of judicial review of the legality of Community measures of general application different from that established by the founding Treaty and never amended as to its principles, it is for the Member States, if necessary, ... to reform the system currently in force. ${ }^{119}$

\section{The Proposal of the European Convention ${ }^{120}$}

Although the Jégo-Quéré test, as well as Advocate General Jacobs's, were only partially convincing, the conservative decision of the ECJ, despite being in se coherent, leaves unresolved all the problems that have been highlighted with regard to Article 230(4) of the ECT. On one point, though, the ECJ is correct: the reform of standing for private applicants under Article 230(4) of the ECT requires an amendment of the Treaty. ${ }^{121}$

The Convention, whose work was completed in June 2003, has taken into consideration this jurisprudential debate when drafting the Treaty Establishing a Constitution for Europe (Eur. Const.). ${ }^{122}$ This text does indeed contain an addition to Article 230(4) of the ECT to the effect that individuals may bring an action for annulment "against a regulatory act which is of direct concern to him or her and does not entail implementing measures." It should be noted first that, under the proposed text, regulatory acts may be challenged regardless of whether they are of individual concern to the applicant. This novelty vis-à-vis the current Article 230(4) of the ECT was introduced as a (perhaps emotional)

118. Id. See also Jégo-Quéré (Judgment of the Court of 1 April 2004) at Grounds of the Judgment, para. 36.

119. Unión de Pequeños Agricultores, 2002 E.C.R. I-6677 at Grounds of the Judgment, para. 45.

120. The European Convention was established by the European Council of Laeken of December 15,2001 with the task of debating the issue of the creation of a European Constitution and of drafting a proposal for a Constitutional Treaty.

121. Cf. Arnull, supra note 43, at 52 .

122. The EU Constitution was signed on Oct. 29, 2004. It will enter into force only after each of the signatory States has ratified it according to their respective constitutional law. See Treaty Establishing a Constitution for Europe, supra note 57. 
reaction to the CFI's Jégo-Quéré judgment whereby, in the absence of effective remedies before national courts, the inadmissibility of a challenge to a detailed regulation under Article 230(4) of the ECT amounts to a violation of the individual's right to an effective remedy. ${ }^{123}$

Under Article 32(1) of the Eur. Const., European regulations are nonlegislative acts of general application that serve the implementation of legislative acts and of certain specific provisions of the Eur. Const. ${ }^{124}$ They may be directly applicable. ${ }^{125}$ There are two categories of European regulations: delegated regulations and implementing acts. Delegated regulations have the object of "supplement[ing] or amend[ing] certain non-essential elements" of EC legislative acts (European "law[s] and framework law[s]," i.e., the current regulations and directives in the sense of Article 249 of the ECT) ${ }^{126}$ Implementing acts are acts of the Commission or the Council laying down measures necessary "to implement legally-binding [EU] acts." ${ }^{27}$ An example of a regulatory act would be the regulation contested in Jégo-Quéré, which was of general application, but laid down detailed provisions, and was directly applicable.

I agree with this approach to differentiate the conditions of admissibility according to the type of act concerned. I also appreciate the effort of the Eur. Const. to ensure and improve the effectiveness of the EC remedies system. As already illustrated above, the Plaumann test is too strict in certain circumstances. The solution chosen by the Eur. Const., however, is too broad. Because the only requirement is direct concern, once this is found any individual who has interest in the annulment of a regulatory act can challenge it. This entails the risk of opening the floodgates for annulment actions brought by individuals who have a very faint interest in the annulment of a measure of general application. The EC judiciary may then be tempted to give more importance to the requirement of interest in bringing proceedings (intérêt à agir), which has been introduced

123. Case T-177/01, Jégo-Quéré v. Commission, 2002 E.C.R. II-2365, Grounds of the Judgment, para. 47.

124. Treaty Establishing a Constitution for Europe, supra note 57, art. I-33 ("A European regulation shall be a non-legislative act of general application for the implementation of legislative acts and of certain provisions of the Constitution. It may either be binding in its entirety and directly applicable in all Member States, or be binding, as to the result to be achieved, upon each Member State to which it is addressed, but shall leave the national authorities the choice of form and methods.").

125. Id.

126. Id. art. I-36.

127. Id. art. I-37. 
through the development of the case law. ${ }^{128}$ It is not sure, though, that this solution would be suitable. The object of reforming Article 230(4) of the ECT should not be to make the admissibility of actions for annulment wide open. It is rather to craft the admissibility criteria under Article 230(4) of the ECT in such a way that locus standi is granted to all individuals who are considerably concerned by a measure, and only those individuals.

\section{Reform Proposal: Different Tests for Different Categories}

A more careful and differentiated reform of Article 230(4) of the ECT is, in my view, necessary to ensure both effective judicial protection and docket control. The starting point is to consider the cases in which a direct action is definitely needed for the purposes of effective judicial protection and, therefore, in which standing to bring an action for annulment should be granted to individuals under Article 230(4) of the ECT. In my view, such cases are as follows:

(1) where the individual is the addressee of an administrative act;

(2) where the nonaddressees of an administrative act are concerned by it directly and individually in such a way that they can claim a current or very probable violation of their individual rights entailing irreparable and serious damages; ${ }^{129}$ or

(3) where a measure is formulated in abstract and general terms but its content is quite specific or its scope of application is quite limited, the individuals who can show that, because of their personal characteristics, the measure is in its effects similar to an administrative measure for them, should be treated, according to the case, like addressees under (1) or like nonaddressees under (2).

Each category deals with a different situation, for each of which it is appropriate to have a test that is at least partially different. As to the first category, locus standi should be automatic. This corresponds to the first part of Article 230(4) of the ECT as currently in force.

The test proposed for the second category is analogous to Advocate General Jacobs's test. Although it builds on cases in which the ECJ applied Plaumann

128. See Case C-50/00 P, Unión de Pequeños Agricultores v. Council, 2002 E.C.R. I-6677, Opinion of the Advocate General, para. 79.

129. Cf. id. para. 60; Case C-50/00 P, Unión de Pequeños Agricultores v. Council, 2002 E.C.R. I6677 , Opinion of the Advocate General. See supra text accompanying note 89. 
broadly, it is a little laxer than Plaumann as usually applied. Moreover, it is of general application, whereas Plaumann, as developed in the case law, applies a lower standard of scrutiny only with regard to certain rights (for example, procedural rights and an individual's right to have his position to be taken into account by the institution). It should be noted that the focus of the test proposed under (2) is not on the question of whether the nonaddressee is concerned in the same way as if he were the addressee. It is rather whether the individual's human rights are or are likely to be violated with the risk of irreparable and serious damages. It is relevant to refer to human rights because the significance of the individual's human rights protection has steadily increased in EC law, first by prætorian development and then Treaty amendments. Accordingly, a violation of the individual's human rights should be a condition for locus standi under Article 230(4) of the ECT. However, given that an administrative measure can potentially violate, maybe even indirectly or slightly, the individual rights of a great number of persons, in light of the docket control principle, it is necessary to shrink the pool of possible applicants by adding the requirement concerning the risk of irreparable and serious damages. ${ }^{130}$ This is appropriate because those who risk suffering such damages may at best find effective judicial protection by way of a direct action.

Under the proposed test, the applicant in a case such as Deutsche Lebensmittelwerke would have standing under Article 230(4) of the ECT. ${ }^{131}$ This case concerned a Commission decision that aimed to support the sales of butter in Berlin by giving with each piece of butter sold, a free piece, stemming from the Community reserves. ${ }^{132}$ The applicant was a margarine producer having a 66 percent market share in the adjacent market of margarine. ${ }^{133}$ The ECJ denied locus standi by strictly applying the Plaumann test. ${ }^{134}$

The third category regards measures that are formulated in general and abstract terms, but their content is quite specific or their scope of application is quite limited. An example thereof is the regulation contested in Codorniu which reserved the term crémant to certain quality wines produced in France and Lux-

130. See Unión de Pequeños Agricultores, 2002 E.C.R. I-6677 at Opinion of the Advocate General, para. 60 .

131. Case 97/85 R, Union Deutsche Lebensmittelwerke GmbH v. Commission, 1985 E.C.R. 1331.

132. Id. paras. $1-5$.

133. Id. para. 5.

134. Id. para. 19. 
embourg. ${ }^{135}$ This regulation, despite being formulated in abstract terms, had a specific content (it concerned the wine crémant and the right to produce it by undertakings in certain limited areas) and affected de facto only very few producers. There is a very fine line between measures of normative and administrative nature: several measures fall into a gray area, so that they could be considered normative as well as administrative. Therefore, it seems unwarranted to draw, as the Eur. Const. does, important legal conclusions such as locus standi from the uncertain categorization of the challenged measure as administrative or normative, given that the result also depends on the form (regulation or decision) a measure takes.

For the purposes of locus standi, it appears suitable to take different approaches according to the degree of abstractness of the provision in question. Where a measure is formulated in abstract and general terms, but its content is quite specific or its scope of application is quite limited (as was the case in Codorniu and Jégo-Quéré), it seems appropriate that the test laid down for administrative decisions is also applied to those applicants who are affected in a very specific manner by a legislative measure. Indeed, for these individuals the contested measure is, in terms of its effects, tantamount to an administrative measure. ${ }^{136}$ This approach seems in conformity with the idea underlying the part of Article 230(4) of the ECT that mentions the possibility of challenging decisions in the form of a regulation. The appropriateness of this approach also finds an indirect confirmation in the CFI's case law. Although it never explicitly did so, the CFI seems to apply the Plaumann test more strictly to legislative measures than to administrative ones. ${ }^{137}$

Where the condition under (3) is met, the question of locus standi should be assessed in two different ways according to the position of the applicants. If the individuals are like addressees of the measure in question, their locus standi should be automatic, as provided for under (1). If they are like nonaddressees, locus standi should be granted where the contested measure encroaches or is likely to encroach on their rights with the risk of serious and irreparable damages, as laid down under (2). For this category of individuals the CFI in Jégo-Quéré and Advocate

135. Case C-309/89, Codorniu SA v. Council, 1994 E.C.R. I-1853, paras. 21-22.

136. See Case C-50/00 P, Unión de Pequeños Agricultores v. Council, 2002 E.C.R. I-6677, Grounds of the Judgment, para. 36 ("[A] measure of general application such as a regulation can, in certain circumstances, be of individual concern to certain natural or legal persons and is thus in the nature of a decision in their regard.") (emphasis added).

137. Arnull, supra note 43, at 22. 
General Jacobs in UPA were right when they denounced the limited effectiveness of Article 234 of the ECT. Under such circumstances, the denial of locus standi would result in a denial of justice, because given the risk of serious and irreparable damages, access to the EC judiciary via Article 234 of the ECT would not be sufficiently effective. Therefore, such a category of individuals must have standing to bring an action for annulment. This solution is dictated by the paradigm of the completeness of the EC system of judicial remedies as recognized in the case law. ${ }^{138}$ However, to establish locus standi it is irrelevant whether the applicants have demonstrated that national remedies would be insufficient to protect the rights.

Finally, with respect to measures that are truly abstract and general, such as the regulation introducing the Euro, it is submitted that individuals should not be able to challenge them under Article 230(4) of the ECT. Indeed, allowing individuals to have standing to challenge truly normative acts would run the risk of turning Article 230(4) of the ECT into a vehicle for public interest litigation, which in my view, is inappropriate given the abstract character of the judicial review it would provoke. Truly general measures may be challenged before national courts, which in turn, may or must refer the question of validity to the ECJ under Article 234 of the ECT. This is what usually happens in most national systems, even in those systems such as Germany's, where an individual action such as a Verfassungsbeschwerde is provided for.

\section{Conclusion}

Functional representation of the individual's interests can be conceived of as an alternative to the individual's political representation. This is in many regards appealing, especially in relation to the EU. Indeed, for individuals, access to the EC courts can entail, in certain circumstances, an extremely effective protection of their rights, and thus a remedy for some of the drawbacks resulting from the democratic deficit in the EC. Therefore, the functional representation of the individual's interests should be fully taken into account when tackling the difficult question of how to reform the EC judicial system. In this regard, docket control measures, if well crafted, do not contradict the aim of functional representation of the individual's interests. On the contrary, under the present circumstances they may well contribute to it.

138. See Unión de Pequeños Agricultores, 2002 E.C.R. I-6677 at Grounds of the Judgment, para. 40. 
Subscribing to the theory of the functional representation of the individual's interests may have profound constitutional law implications, in that it may affect the concept of democracy. To deem functional representation to constitute an alternative to political representation contributes, among other things, to the reinforcement of the democratic concept focusing on the individual rather than the people of a state (Staatsvolk) as the central category. This is in my view to be welcomed, especially after the Staatsvolk has rediscovered charm that seemed lost. ${ }^{139}$

Nonetheless, the functional representation of the individual's interests should, as in the case of any theory, not be taken to extremes. It is true that it could rely on the consideration that, in today's Europe, one of the sources of the legitimacy of the exercise of public powers is the constitution and, more generally, the rule of law. ${ }^{140}$ However, the other-and admittedly more importantsource of the legitimacy of the exercise of the public powers is still accountability to the citizens through elections, political parties, and public opinion. Therefore, the functional representation of the individual's interests can only partially substitute for their political representation. Thus, the theory of the functional representation of the individual's interests offers a valid conceptual framework for the legitimation of judicial activism. At the same time, it may also constitute useful guidance for the decision of when judicial activism should stop and judicial self-restraint should be exercised.

139. See, e.g., Germany: Federal Constitutional Court Decision Concerning the Maastricht Treaty, 33 I.L.M. 388 (1994) (decision of the German Federal Constitutional Court of October 12, 1993).

140. Cf. SwEET, supra note 16, at 133 (holding that in today's Europe, the common source of all legality, and therefore of political legitimacy, is the constitution); id. at 196 (holding that the ideology of parliamentary sovereignty has been undermined by that of modern constitutionalism). 